Article

David Kleist*

\title{
The Multilateral Convention to Implement Tax Treaty Related Measures to Prevent BEPS-Some Thoughts on Complexity and Uncertainty
}

https://doi.org/10.1515/ntaxj-2018-0001

Received Oct 25, 2017; accepted Jan 29, 2018

\begin{abstract}
The Multilateral Convention to Implement Tax Treaty Related Measures to Prevent Base Erosion and Profit Shifting (MLI), which was signed in June 2017, raises a multitude of questions relating not only to the text of the treaty provisions but also to the way the MLI will interact with tax treaties, for instance, and what it will mean for the future development of tax treaty law and international cooperation in tax matters. This article focuses on two aspects of the MLI. First, it deals with the substance of the MLI by providing an overview of its background and content, including the many options available to the contracting states under the MLI. Second, some thoughts are presented on the effects of the MLI in terms of complexity and uncertainty.
\end{abstract}

Keywords: Tax treaty, Multilateral instrument, MLI, BEPS, base erosion, rule complexity, legal uncertainty, Multilateral Convention to Implement Tax Treaty Related Measures, PPT, principal purpose test, treaty antiabuse rules

\section{Introduction}

Some 100 states have participated in the development of a new multilateral convention designed for the swift implementation of the tax-treaty-related measures agreed upon as part of the Organization for Economic Cooperation and Development's (OECD) so-called Base Erosion and Profit Shifting (BEPS) Project. The convention is entitled "The Multilateral Convention to Implement Tax Treaty Related Measures to Prevent Base Erosion and Profit Shifting" and is often referred to as the Multilateral Instrument (MLI). A text was agreed upon in November 2016, and formal

\footnotetext{
*Corresponding Author: David Kleist: Associate Professor (Docent) of Tax Law in the Department of Law at the School of Business, Economics and Law, University of Gothenburg; Email: david.kleist@law.gu.se
}

signing took place on June 7, 2017. At the end of the year, 78 states and jurisdictions had signed or had expressed their intention to sign the instrument. When the MLI enters into force, it will modify existing tax treaty provisions and add new provisions to tax treaties entered into between the parties to the MLI, potentially affecting more than 2,000 tax treaties. The MLI represents a completely new approach to implementing tax treaty changes.

The MLI raises a multitude of questions, relating not only to the text of the treaty provisions but also to issues such as the way the MLI will interact with tax treaties and what it will mean for the future development of tax treaty law and international cooperation in tax matters.

This article focuses on two aspects of the MLI. First, it deals with the substance of the MLI by providing an overview of its background and content, including the many options available to the contracting states under the MLI in connection with and subsequent to its conclusion. This part of the article is introduced in Section 2. As the purpose of this part is mainly to give an overview, readers already well acquainted with the MLI may choose to skip this section. Second, some thoughts on the effects of the MLI in terms of complexity and uncertainty are presented in Section 3. Finally, the conclusions are summarized in Section 4.

\section{The Multilateral Instrument}

\subsection{Purpose of the Multilateral Instrument}

In recent years, the tax planning of multinational enterprises has come into focus in the public debate, giving rise to the political will to show leadership in restricting opportunities for tax planning, particularly tax planning relating to so-called Base Erosion and Profit Shifting (BEPS). Primarily, BEPS refers to opportunities for taxpayers to benefit from gaps and mismatches in the tax rules that are applicable to international transactions and to shift taxable income from high-tax to low-tax jurisdictions by 
entering into agreements with associated enterprises on terms that would not have been agreed on by independent parties. Politicians have given the OECD a leading role in this work, and in response, the OECD has developed and presented a 15-item Action Plan intended to provide governments with means for counteracting BEPS.

After two years, the measures developed in the course of the work on BEPS were presented in the form of reports on each of the 15 actions, accompanied by an Explanatory Statement-the so-called Final BEPS Package. According to the OECD, the Final BEPS Package gives countries and economies the required tools to ensure that profits are taxed where economic activities generating profits are performed and where value is created, while simultaneously providing businesses with greater certainty by reducing disputes over the application of international tax rules and standardizing compliance requirements (OECD 2016).

Many of the measures proposed under the 15 actions concern the design of states' domestic law and thus presuppose that changes are made to domestic law insofar as it is not already consistent with the recommendations presented by the OECD. In many cases, the adaptation of a state's domestic law on basis of the OECD recommendations is aimed at increasing the taxing rights of that state in order to eliminate tax benefits that could otherwise have arisen through tax planning. As tax treaties limit the contracting states' taxing rights and generally have priority over domestic law, however, changes to the domestic law that increase a state's taxing rights may become ineffective where there is a tax treaty in place. As a consequence, basically all tax treaties entered into by the states that are involved in the BEPS Project must be amended in accordance with the domestic law changes proposed as part of the Final BEPS Package, if these changes are to become fully effective. Furthermore, some of the measures of the Final BEPS Package, such as the introduction of treaty antiabuse rules, specifically address tax treaty issues and thus require that changes be made to existing tax treaties.

Consequently, for the BEPS measures to become fully effective, a number of changes must be implemented in the tax treaties of the states involved in the project. Normally, that could be expected to occur through changes in the OECD Model Tax Convention on Income and on Capital (OECD Model Tax Convention) that would then be reflected in tax treaties, as they are being renegotiated. In other words, each tax treaty would have to be renegotiated in order for the BEPS changes to become fully effective among all states participating in the BEPS Project. Worldwide, there are more than 3,000 individual tax treaties (OECD 2016). So, although not all states that have entered into tax treaties participate in the BEPS Project, the changes concern a large number of tax treaties. Renegotiating such a large number of tax treaties could take years or even decades, meaning that the changes would gradually become effective over many years. Thus, in order to address BEPS efficiently within a reasonable time frame, a mechanism to facilitate swifter implementation of tax treaty changes is required. This is where the MLI-item 15 of the BEPS Action Plan-is intended to play a vital role.

In addition, the outcome of a renegotiation of all tax treaties would be uncertain; because the OECD Model Tax Convention is not binding, states are free to deviate from the model when negotiating tax treaties. ${ }^{1}$ Implementation of tax treaty changes through a multilateral convention rather than through bilateral negotiations reduces the risk that states advance their own solutions when implementing BEPS measures, which would be contrary to the intention of addressing BEPS issues in a comprehensive and coordinated manner.

The general purpose of the MLI to reduce opportunities for taxpayers to benefit from gaps and mismatches in the tax rules that are applicable to international transactions and shift taxable income from high-tax to low-tax jurisdictions is underlined by the preamble of the MLI, which notes:

the need to ensure that existing agreements for the avoidance of
double taxation on income are interpreted to eliminate double
taxation with respect to the taxes covered by those agreements
without creating opportunities for non-taxation or reduced tax-
ation through tax evasion or avoidance and by Article 6(1) of the MLI, which modifies tax treaties covered by the MLI to include a corresponding preamble text.

\subsection{The Negotiation}

Item 15 of the Action Plan, presented by the OECD in 2013, was to analyze the "tax and public international law issues related to the development of a multilateral instrument to enable jurisdictions that wish to do so to implement measures developed in the course of the work on BEPS and amend bilateral tax treaties" (OECD 2013). In

1 The OECD recommends that the Member States follow the OECD Model. That recommendation in its most recent version was adopted on October 23, 1997. The English language version of the recommendation contains the following statement: "THE COUNCIL / ... / RECOMMENDS the Governments of member countries / ... / when concluding new bilateral conventions or revising existing bilateral conventions, to conform to the Model Tax Convention." 
2014, a report entitled "Developing a Multilateral Instrument to Modify Bilateral Tax Treaties" was adopted by the OECD Committee on Fiscal Affairs and endorsed by the G20 leaders (OECD 2014). This report was followed by a final report in 2015, which basically reiterated the 2014 report and provided a mandate to form a group for the development of the MLI (OECD 2015a). All interested states were invited to participate. Work on reaching an agreement on a multilateral convention to amend tax treaties began in 2015, initially with the participation of some 80 countries (OECD Member States and non-members). ${ }^{2}$ The number of participating countries subsequently grew to 99 . In addition, four non-state jurisdictions and seven international organizations participated as observers (OECD 2016). As mentioned, the negotiations were concluded in November 2016, and the text of the MLI was adopted. A signing ceremony was held on June 7,2017 , and at the end of the year, 78 countries and jurisdictions had signed or expressed their intention to sign the MLI (OECD 2017a). When the negotiating states adopted the text of the MLI, they also adopted an 85-page Explanatory Statement (MLI Explanatory Statement; OECD 2016).

The time plan for the negotiations-that the negotiations were to be concluded by the end of 2016-was extremely ambitious. Experience shows that trying to reach international consensus on tax matters is a difficult and typically time-consuming task. It is indeed impressive that an agreement could be reached within that limited timeframe.

\subsection{Entry into Force and Withdrawal}

The MLI did not become binding on the signatory states when it was signed in June 2017. According to Article 34(1) of the MLI, it will "enter into force on the first day of the month following the expiration of a period of three calendar months beginning on the date of deposit of the fifth instrument of ratification, acceptance or approval”. In other words, a minimum number of five ratifying states are required in order for the MLI to enter into force and become legally binding on the parties that have ratified the MLI as of that date.

For each signatory ratifying, accepting, or approving the MLI after "the deposit of the fifth instrument of rati-

2 Even though non-Member States are invited to participate in the negotiation, the procedure can been criticized for lacking legitimacy, as not all states have been allowed to participate on equal terms in the development of the BEPS measures that are to be implemented through the MLI (Mosquera Valderrama 2015). fication, acceptance or approval”, the MLI shall, according to Article 34(2), "enter into force on the first day of the month following the expiration of a period of three calendar months beginning on the date of the deposit" of such instrument.

The fact that entry into force in relation to a state requires ratification by that state means that each signatory state will deal with the MLI in accordance with its own legal system and national procedures before it can enter into force. Typically, parliamentary approval is required, which means that the ratification procedure in a state can be halted by domestic political strife, for example. Furthermore, depending on the relation between international law and domestic law in the state in question, enactment of legislation may be required in order for the MLI to exercise influence on taxpayers, authorities, and courts. In order for a party to be given sufficient time to complete its required internal procedures, Article 35(7) of the MLI allows for a reservation that extends the time of entry into force until 30 days after the receipt by the Depositary of a notification by the reserving state that it has completed its internal procedure. ${ }^{3}$

The effect of the MLI may also be delayed because, according to Articles 1 and 2 of the MLI, a tax treaty will be covered by the MLI only when each party to the tax treaty has notified a Depositary listing the tax treaty and any amending instruments thereto and, in regard to extensions of the list of tax treaties, according to Article 35(5) of the MLI, then only after a period of time following the notification of the tax treaty. Given that the MLI provides for a number of options and that these options must be coordinated to some extent between the contracting states to each tax treaty before notification to the Depositary of the tax treaty in question is made, ${ }^{4}$ it may take some time before a party to the MLI has been able to make the MLI applicable to all tax treaties it wants to be covered by the MLI.

According to Article 37(1) of the MLI, it is possible to withdraw from the MLI, but insofar as the MLI, before the withdrawal, has entered into force with respect to a tax treaty, it follows from Article 37(2) of the MLI that the tax treaty remains modified by the MLI.

3 In regard to the implementation of the MLI into Swedish domestic law, see Engsbråten (2017).

4 There may also be a need to agree bilaterally on specific issues, see, for example, Art. 7(9)(d)(i) of the MLI and MLI Explanatory Statement, para. 106, concerning the nonprofit organizations that qualify for treaty benefits under the optional simplified limitation on benefits provision. 


\subsection{The Relation Between the Multilateral Instrument and Existing Tax Treaties}

The MLI does not replace existing tax treaties but instead operates to modify them in certain respects. Thus, the MLI will be applied alongside existing tax treaties. To the extent that a tax treaty and the MLI cannot be reconciled, the idea has been to address the conflict through compatibility clauses that give the provisions of the MLI priority, meaning that existing tax treaty provisions will, in effect, be replaced by provisions of the MLI or that the application of an existing provision will be changed without the provision being removed. In other cases, the MLI will add new provisions to the existing tax treaty provisions.

The provisions of the MLI that implement BEPS measures typically contain a compatibility clause stating that the provision in question "shall apply in place of or in the absence of provisions of the Covered Tax Agreement" that address the same subject matter as the MLI provision. ${ }^{5}$ Thus, the MLI provision will apply in all cases, regardless of whether there is an existing provision and regardless of the notifications made by the parties to a Covered Tax Agreement. Other forms of modifications require notification to the Depositary by both (or all) contracting states to a tax treaty of the existence or absence of an existing provision (OECD 2017b; para. 22). The fact that a tax treaty is covered by the MLI does not prevent the contracting states from amending the treaty through bilateral negotiation. ${ }^{6}$

\subsection{Flexibility}

Although practically all tax treaties existing today essentially conform to either the OECD Model Tax Convention or the version of that model that has been developed by the United Nations, tax treaties frequently contain deviations from the model conventions. Such deviations may be due to the economic and political preferences of the contracting states, their relative bargaining position, and the level of mutual concessions agreed upon, for example.

Given the differences in economic and political preferences, it would hardly have been possible to agree on one set of tax treaty provisions that would modify in the same way all tax treaties entered into by the MLI signatories. Moreover, tax treaties may differ because they were modeled on different versions of the OECD Model Tax Con-

5 Art. 3(4), Art. 4(2), Art. 6(2), Art. 7(2), Art. 7(14), Art. 8(2), Art. 9(2), Art. 9(5), Art. 10(4), Art. 11(2), Art. 14(2), Art. 16(4)(a)(i), Art. 16(4)(a)(ii), Art. 17(2), and Art. 26(1) of the MLI.

6 This has been clarified in Art. 30 of the MLI. vention or because they have been authenticated in different languages, or simply because they use different terminology. As each tax treaty reflects factors that are specific to the bilateral relation of the contracting states, imposing one set of amending tax treaty provisions to all tax treaties entered into by the parties to the MLI could have disrupted the balance achieved through bilateral negotiation.

In order to ensure broad participation, it was deemed necessary to make the MLI flexible enough to accommodate the positions of different countries and jurisdictions. The MLI also needed to provide flexibility in relation to provisions in existing tax treaties that differ for various reasons (OECD 2016; see para. 14).

Flexibility is achieved in the MLI in several ways, including a mechanism that follows from Articles 1 and 2 of the MLI. According to Article 1, the MLI modifies so-called Covered Tax Agreements. Article 2 defines a Covered Tax Agreement as a double tax treaty with respect to which each party to the tax treaty has made a notification to a Depositary administered by the OECD. ${ }^{7}$ This means that a party can decide to exclude a tax treaty that it has entered into from the scope of application of the MLI simply by choosing not to notify it to the Depositary. According to the OECD, more than $85 \%$ of the tax treaties concluded among the signatories of the MLI are already covered by the MLI, and more treaties are likely to be notified when the signatories have finalized their discussions on coordination of their respective choices relating to the contents of the MLI (OECD 2017d).

Some provisions of the MLI reflect a minimum standard and, as such, can be satisfied in different ways. In some cases, the MLI itself provides for different ways of meeting the minimum standard. If two contracting states to a treaty implement a minimum standard in different ways, however, it may give rise to inconsistencies in the tax treaty. To avoid such inconsistencies, the contracting states are urged to coordinate their choices with respect to implementation of the minimum standard. The coordination of choices in effect reduces the flexibility to some extent (OECD 2016; para. 14). Similarly, some optional provisions may be deemed inappropriate to apply when both (or, in case of a multilateral tax treaty, all) parties to an existing tax treaty have not made the same choices, as the provisions could then disrupt the balance of the tax treaty. Consequently, there may be a need to coordinate the measures taken by the contracting states in this regard as well (OECD 2016; paras. 101-103). ${ }^{8}$

\footnotetext{
7 In regard to the Depositary, see Section 2.6.
} 8 See, for example, Art. 7(16) of the MLI. 
Where a provision does not reflect a minimum standard, the MLI generally allows for an opting out of that provision entirely or, in some cases, out of part of that provision. Opting out is accomplished by making a reservation. Each article specifically sets out the permitted reservations. When a party uses a reservation to opt out of a provision of the MLI or to opt out of a part of a provision, that provision or part of a provision will not apply between the reserving party and the other parties to the MLI, unless explicitly provided otherwise in the relevant provisions. ${ }^{9} \mathrm{Ac}-$ cordingly, unless expressly provided otherwise in the relevant provision, none of the tax treaties entered into by the reserving party will be modified by the provision or part of the provision that the party in question has opted out of. In some cases, however, the MLI permits a party to opt out of a provision in respect of specific tax treaties (OECD 2016; para. 14).

As follows from Article 28(1) of the MLI, reservations are expressly permitted in relation to 27 provisions of 21 Articles. ${ }^{10}$ The fact that Article 28(1) lists the paragraphs in respect of which reservations are permitted does not mean, however, that only 27 different reservations are possible. Under Article 3 on transparent entities, for instance, a party may reserve the right not to apply the entire Article 3, not to apply either paragraph 1 or 2 of Article 3 to its Covered Tax Agreements, not to apply paragraph 1 to a tax treaty that already contains a provision that deals with transparent entities, or not to apply paragraph 1 to a tax treaty that already contains such a provision in respect of entities established in a third jurisdiction. A party may also reserve the right not to apply paragraph 1 to tax treaties that already contain a provision aimed at fiscally transparent entities, which identifies in detail a treatment of specific fact patterns and types of entities or arrangements or which identifies such fact patterns and types of entities or arrangements and denies treaty benefits in the case of income derived by or through an entity or arrangement established in a third jurisdiction. ${ }^{11}$ Reservations that limit the scope of the article in seven different ways can thus be identified in respect of Article 3 alone. So although it is not possible to make a reservation to any paragraph of the MLI, the reservations that are allowed may take many different forms and may have different scopes.

9 Art. 28(3) of the MLI.

10 A party that chooses to apply mandatory binding arbitration may, according to Article 28(2) of the MLI, also formulate reservations with respect to the scope of cases that shall be eligible for arbitration. 11 Art. 3(5) of the MLI.
Flexibility in the MLI has also been achieved in a number of cases by allowing parties to choose between two or more provisions or by providing for optional, additional provisions. Such provisions will generally apply only if all parties to a tax treaty covered by the MLI have decided to apply them.

To ensure clarity, the choices made by a party under the MLI in respect of reservations and in respect of alternative and optional provisions shall be notified to the Depositary. Similarly, where a provision of the MLI supersedes or modifies specific types of existing provisions, parties are generally required to make a notification specifying which tax treaties contain provisions of that type. The effect of such notifications depends on the type of compatibility clause (OECD 2016; para. 15).

\subsection{The Depositary}

A key function is attributed to the so-called Depositary. For instance, according to Article 1 and Article 2(1) of the MLI, notification of a tax treaty to the Depositary by each party to the tax treaty is required in order for the treaty to be covered by the MLI. Furthermore, as mentioned, options given and reservations permitted in the MLI require that notification to the Depositary be made. The notification may relate to the choice made and, in some cases, also specifies the tax treaties in respect of which the choice applies. Moreover, where a provision of the MLI supersedes or modifies specific types of existing provisions, parties are generally required to make a notification specifying which tax treaties contain provisions of that type. In addition, the Depositary shall notify the parties and signatories of the MLI of inter alia new signatories, the deposit of new instruments of ratification, and new reservations. According to Article 39 of the MLI, the Secretary-General of the OECD shall be the Depositary of the MLI. The Depositary maintains a publicly available list of Covered Tax Agreements and of reservations and notifications made by the Parties. The information is provided to the Depositary by each jurisdiction in the form of a completed template and constitutes that jurisdiction's MLI position (OECD 2017b; para. 21).

Reservations and notifications shall be made to the Depositary at the time of signature or when depositing the instrument of ratification. ${ }^{12}$ If reservations and notifications are made at the time of signature, they shall be con-

12 Art. 28(5) and Art. 29(1) of the MLI. 
firmed upon deposit of the instrument of ratification..$^{13}$ If reservations and notifications are not made at the time of signature, then a provisional list of expected reservations and notifications shall be handed in to the Depositary at that time. ${ }^{14}$ Thus, in connection with signing, each signatory state must prepare and submit its position with respect to the various options provided for in the MLI.

Subsequent to ratification, reservations can be withdrawn or replaced with more limited reservations by means of a notification addressed to the Depositary. ${ }^{15} \mathrm{Ad}-$ ditional notifications can also be made at a later date. For instance, a signatory can opt in with respect to optional provisions. In such cases, the additional notifications do not take effect immediately. ${ }^{16}$ Furthermore, notification of additional tax treaties to be covered by the MLI and reservations and notifications relating to such tax treaties may also be made subsequent to the deposition of the instrument of ratification. ${ }^{17}$

\subsection{Tax Treaty Modifications Implemented through the Multilateral Instrument}

\subsubsection{Outline of the Multilateral Instrument}

The MLI is a 48-page document that is outlined as follows.

- Preambles

- Part I. Scope and Interpretation of Terms (Articles 12)

- Part II. Hybrid Mismatches (Articles 3-5)

- Part III. Treaty Abuse (Articles 6-11)

- Part IV. Avoidance of Permanent Establishment Status (Articles 12-15)

- Part V. Improving Dispute Resolution (Articles 1617)

- Part VI. Arbitration (Articles 18-26)

- Part VII. Final Provisions (Articles 27-39)

Some of the initial and final articles of the MLI have been commented on in Sections 2.1, 2.3, 2.5, and 2.6. In Sections 2.7.1-2.7.6 the articles set out in Parts II-VI are briefly described-the articles that modify the substantive provisions of existing tax treaties. The MLI text is extensive and, in some respects, highly technical. The overview given in

13 Art. 28(6) and Art. 29(3) of the MLI. 14 Art. 28(7) and Art. 29(4) of the MLI. 15 Art. 28(9) of the MLI. 16 Art. 29(6) of the MLI. 17 Art. 29(5) of the MLI. this section deals only with the main aspects of the provisions and does not go into detail.

\subsubsection{Hybrid Mismatches (Articles 3-5)}

The goal of Articles 3-5 of the MLI is to deal with so-called hybrid mismatches. As tax systems are national and, in principle, are not coordinated, legal concepts may have different meanings in different states. Taxpayers can take advantage of these mismatches in their tax planning. For instance, a payment under a specific financial instrument may be classified in the state of the payer as deductible interest while being classified as tax-exempt dividends in the state of the recipient-in effect leading to double nontaxation. Correspondingly, a legal entity may be regarded as transparent for tax purposes in the state where it is created; whereas the state in which the owners are resident classifies it as a taxable entity, which can result in nontaxation of income derived by that entity. Lack of coordination of tax systems can also lead to a deduction being allowed for the same cost in more than one state.

Article 3 addresses certain forms of tax planning that entail income earned through transparent entities. It implements the new Article 1(2) of the OECD Model Tax Convention, which has been included in the 2017 version of the model treaty, and also modifies the provisions concerning elimination of double taxation.

Where a taxpayer is considered by each contracting state to a tax treaty to be a resident of that state under the treaty, it may result in a double deduction for the same costs (i.e., deduction in both states) or other unintended tax benefits. Article 4 of the MLI deals with these situations of dual residence for taxpayers other than individuals and is based on the new text of Article 4(3) of the OECD Model Tax Convention, which has been included in the 2017 version of the model treaty. The goal is to ensure that a taxpayer shall be considered a resident of only one contracting state. This shall be achieved by means of a mutual agreement procedure. Furthermore, Article 4 of the MLI provides that, if the contracting states cannot come to an agreement, the taxpayer shall not be entitled to tax relief under the treaty, except to the extent agreed upon by the competent authorities of the contracting states.

Article 5 of the MLI modifies the double-tax-relief article of existing treaties in order to avoid double nontaxation because of the application of the exemption method to income that is not taxed in the state of source. The article provides for three options. The first option, which is based on Article 23A(4) of the OECD Model Tax Convention, provides for a switch to the credit method 
when the source state applies the provisions of an existing tax treaty to exempt income or to limit the rate at which that income may be taxed. The second option also provides for a switchover to the credit method but is limited to situations in which the state of residence would otherwise have exempted the income as a result of the fact that it treats it as dividends, whereas the source state allows a deduction for the payment under its domestic law, typically as a result of treating it as a payment of interest. This option was drafted during work on the MLI and is not included in any previous report. The third option is to replace the double-tax-relief article of existing tax treaties that provide for the exemption method with a double-tax-relief article that provides for the credit method.

\subsubsection{Treaty Abuse (Articles 6-11)}

Articles 6-11 of the MLI address various forms of tax planning that can be perceived as treaty abuse.

Article 6 of the MLI modifies existing tax treaties to include a preamble text that clarifies the purpose of the double tax treaty as not being solely to eliminate double taxation, but to do so without creating opportunities for non-taxation or reduced taxation through tax evasion or tax avoidance (including through treaty-shopping arrangements aimed at obtaining relief provided in the tax treaty for the indirect benefit of residents of third jurisdictions). As international treaties shall be interpreted in good faith in accordance with the ordinary meaning to be given to the terms of the treaty in their context and in the light of their object and purpose, ${ }^{18}$ the modification of the purpose of the tax treaty set out in the preambles may influence the interpretation of the tax treaty. Article 6 reflects a minimum standard for protection against the abuse of treaties. A party may, therefore, reserve the right for the text not to apply to an existing tax treaty only if that treaty already contains preamble language that describes the same intent or that applies more broadly (OECD 2016; see para. 85 ).

Article 7 of the MLI presents an antiabuse provision in the form of the so-called principal purpose test (PPT), ${ }^{19}$ which since the 2017 update is also included in Article 29(9) of the OECD Model Tax Convention. The PPT provision provides that treaty benefits shall be denied if it is

18 Cf. Art. 31(1) of the Vienna Convention on the Law of Treaties, 23 May 1969, United Nations, Treaty Series, vol. 1155, p. 331. 19 For an analysis of the PPT clause, see Chand (2018). reasonable to conclude, having regard to all relevant facts and circumstances, that obtaining that benefit was one of the principal purposes of any arrangement or transaction that resulted directly or indirectly in that benefit, unless it is established that granting that benefit in these circumstances would be in accordance with the object and purpose of the relevant provisions of the Covered Tax Agreement.

In addition, Article 7 contains an optional "simplified" Limitation on Benefits (LOB) clause covering approximately four pages, which provides that most treaty benefits shall be denied to taxpayers other than individuals unless such other taxpayers fulfill one of a number of criteria. The purpose of the clause is to prevent treaty shopping by denying treaty benefits to companies that are not engaged in the "active conduct of business".

According to Article 7(15) of the MLI, a party may opt out of the PPT provision set out in Article 7(1) but only if it fulfills the minimum standard set out by the MLI in another way-by adopting a combination of a detailed LOB provision and rules to address conduit financing structures, for example. Given that a detailed LOB provision requires substantial bilateral customization, the MLI does not include such a provision (OECD 2016; para. 90). Moreover, a party to the MLI that has chosen the simplified LOB clause may opt out of Article 7 entirely with respect to existing tax treaties where the other contracting state prefers to apply the PPT alone, provided that it endeavors to reach a mutually satisfactory solution that meets the minimum standard (OECD 2016; see para. 113). ${ }^{20}$ In practice, few, if any, tax treaties will fulfill the minimum standard in another way, so that a party may opt out of the PPT provision. Consequently, the MLI will modify all or almost all existing tax treaties to include a PPT provision. As of July 2017, all signatories had chosen to implement the minimum standard with the PPT. In addition, 12 signatories had implemented the PPT supplemented with a simplified LOB clause (OECD 2017d).

Since the 2003 version until the 2014 version of the Model Tax Convention, it has followed from Paragraph 9.5 of the commentary to Article 1 of the Model Tax Convention that "[A] guiding principle is that the benefits of a double taxation convention should not be available where a main purpose for entering into certain transactions or arrangements was to secure a more favourable tax position and obtaining that more favourable treatment in these circumstances would be contrary to the object and purpose of the relevant provisions". The wording of this guiding principle is somewhat similar to the PPT provision of the MLI.

$\overline{20 \text { Art. }}$ (16) of the MLI. 
This raises the question whether the PPT provision implemented through the MLI is such a substantial change after all. In my view, it is. First, there is a big difference between including text in the treaty as opposed to in the commentary. Courts may, depending on the tradition for interpreting tax legislation in the state in question, be hesitant to deny treaty benefits based on the commentary when the prerequisites for doing so are not expressed in the treaty text. Second, even where a court finds that treaty benefits can be denied with reference to the guiding principle expressed in the commentary, it may refrain from doing so when it comes to tax treaties that have been concluded before 2003.

Tax treaties generally provide for a tax rate limit that puts a ceiling on tax payable on dividends paid by a company in a contracting state to a company of the other contracting state. Under Article 10(2)(a) of the OECD Model Tax Convention, the tax charged shall not exceed 5\% of the gross amount of the dividends if the beneficial owner is a company that holds directly at least $25 \%$ of the capital of the company paying the dividends. Prior to the 2017 update, Article 10(2) did not require any specific holding period. Article 8 of the MLI requires that shares be held for 365 consecutive days in order for a company to be entitled to the reduced rate. It implements the new Article 10(2) of the OECD Model Tax Convention (OECD 2016; see para. 118). The provision prevents the lower rate from being applied-where a shareholder increases its shareholding shortly before the dividend becomes payable for the purpose of securing the benefit of the reduced rate, for example (OECD 2015b; see para. 35). It does not affect existing provisions that give a preferential rate for dividends without the condition on holding a certain amount of the capital, such as provisions based on Article 10(2)(b) of the OECD Model Tax Convention, which provides for a tax rate limit of $15 \%$ to other payments of dividends by a company in one contracting state to a resident of the other contracting state (OECD 2016; see para. 119).

According to Article 13 of the OECD Model Tax Convention, capital gains on shares in general are taxable only in the state of residence of the taxpayer, whereas gains derived from the alienation of immovable property and situated in the other contracting state may be taxed in that other state. In order to prevent an increase in value of such immovable property being realized without taxation in the state where the immovable property is situated through of a sale of shares in a company that holds the property, some jurisdictions have introduced rules that provide for taxation in the state where the property is situated when shares are sold by a non-resident shareholder, if the shares have derived a certain part of their value from that immovable property. In order to reserve the taxing right of the jurisdiction where the property is situated, in such situations, Article 13(4) of the OECD Model Tax Convention provides that gains derived by a resident of a contracting state from the alienation of shares deriving more than $50 \%$ of their value directly or indirectly from immovable property in the other state may be taxed in that other state. Article 9 of the MLI, which corresponds to the 2017 update to Article 13 of the OECD Model Tax Convention, amends such provisions of existing tax treaties by stating that they shall apply if the value threshold is met at any time during the 365 days preceding the alienation. The purpose of this amendment is to prevent tax planning whereby taxation in the state where the property is situated is avoided through a contribution of assets to the entity shortly before the sale of shares that dilutes the proportion of the value of the entity that is derived from immovable property. Moreover, Article 9 of the MLI provides that tax treaty provisions that reserve the taxing right of the state where immovable property is situated shall apply not only to the alienation of shares but also to the alienation of comparable interests such as interests in a partnership or trust.

Article 10 of the MLI contains an antiabuse rule for permanent establishments situated in third jurisdictions and provides that treaty benefits can be denied where the state of residence exempts income of a permanent establishment situated in a third state, but only if the income is low taxed in the third state and not derived in connection with the active conduct of business.

Article 11 of the MLI provides that a Covered Tax Agreement shall not affect a contracting state's right to tax its own residents, except with respect to benefits granted under certain provisions of the Covered Tax Agreement. The article is similar to the saving clause that is a longstanding feature of US tax treaty policy but can be viewed as unnecessary, as it leaves the instances of exclusive source state taxation untouched and merely clarifies that other provisions of the Covered Tax Agreement shall not be interpreted as restricting the taxing rights of the state of residence. $^{21}$

\subsubsection{Avoidance of Permanent Establishment Status (Articles 12-15)}

Tax treaties typically provide that the profits of an enterprise in a contracting state shall be taxable only in that

21 For an analysis of the saving clause in the OECD Model Tax Convention, see Kofler (2016). 
state unless the enterprise conducts business in the other contracting state through a permanent establishment situated in that other contracting state. Tax treaties also contain a definition of the term "permanent establishment". The term generally means a fixed place of business such as a place of management, an office or a factory. The definition essentially constitutes a threshold for tax liability of a taxpayer conducting business in the contracting state of which the taxpayer is not a resident. Where the activities of the taxpayer in a state reach or exceed the level established by the permanent establishment definition, the value resulting from those activities is considered to be more closely connected to that state than it is to the state of residence, and it is, therefore, considered appropriate to give the state in which the activities are conducted the primary taxing right to income representing that value.

According to the permanent establishment definition of the OECD Model Tax Convention, the fact that a foreign taxpayer sells goods or services in a state is not in itself sufficient to constitute a permanent establishment. A certain level of physical presence is required. The threshold for tax liability in the contracting state of which the taxpayer is not a resident has been discussed within the framework of the BEPS Project. The development of the digital economy has, to a far greater extent than ever before, made it possible to engage in sales activities without establishing a physical presence in the state where the goods or services are sold and, consequently, without a permanent establishment in that state. It can be argued that the hitherto permanent establishment definition is no longer an appropriate basis for allocating tax jurisdiction. No major revision of the permanent establishment definition has been agreed upon, however. The changes resulting from the BEPS Project provided for in Articles 12-15 of the MLI are mainly aimed at preventing so-called artificial avoidance of permanent establishment status.

According to the 2014 version and earlier versions of the OECD Model Tax Convention, the conclusion of contracts with the assistance of a person in the other contracting state may give rise to a permanent establishment in that state, even if the taxpayer does not have a fixed place of business there-but only if that person has, and habitually exercises, an authority to conclude contracts in the name of the taxpayer. As long as the person does not have that authority, there is no permanent establishment. Article 12, which corresponds to the 2017 update of the model treaty, is intended to widen the scope of the definition of permanent establishment by including certain situations in which contracts are concluded with the assistance of a person in another state, who, although lacking authority to enter into contracts on behalf of the taxpayer, plays a critical role for the conclusion of the contracts. As is the case for tax treaties based on previous versions of the OECD Model Tax Convention, this rule does not apply when the person acting for the enterprise conducts business as an independent agent and acts for the enterprise in the ordinary course of business. The new provisions provide, however, that persons who act exclusively or almost exclusively on behalf of one or more enterprises to which they are closely related shall not be considered independent agents.

The 2014 version of the OECD Model Tax Convention includes a list of exceptions to permanent establishment status applying where a place of business is used for specifically listed activities. For instance, the term "permanent establishment" does not apply to the use of facilities solely for the purpose of storage, display, or delivery of goods or merchandise belonging to the enterprise. According to Article 13 of the MLI (and Article 5 of the 2017 version of the model treaty), such activities will be excluded only if the listed activity or the overall activity of the fixed place of business (taking into account the activities of closely related enterprises) is of a preparatory or auxiliary character.

Article 14 is intended to reduce the opportunities for avoiding permanent establishment status by splitting up the activities performed in the contracting state on several closely related enterprises, so that no individual enterprise performs activities in the territory that meet the degree of permanence required for there to be a permanent establishment.

Article 15 describes the conditions under which a person will be considered closely related to an enterprise for the purposes of Articles 12-14.

Articles 12-15 contain new concepts and terms that are not defined and that are vague and capable of being interpreted differently by different tax authorities. Although the broadening of the permanent establishment definition is said to target artificial avoidance, these concepts and terms could apply to other situations as well. Consequently, the changes to the permanent establishment definition could have a substantial impact on the allocation of tax revenue between the states. In a bilateral negotiation, the losing state would not agree to such a change, at least not without receiving something in return.

As the changes may result in a reallocation of tax revenue between the contracting states, it has not been possible to agree on a minimum standard with regard to the changes to the definition of "permanent establishment". 


\subsubsection{Improving Dispute Resolution (Articles 16-17)}

Articles 16-17 of the MLI contain some of the elements for implementing the agreed minimum standard for improving dispute resolution. Article 16 of the MLI concerns the mutual agreement procedure. It modifies the Covered Tax Agreements to incorporate the contents of revised Article 25, (1) through (3), of the OECD Model Tax Convention that allows a taxpayer to present a case to the competent authority of either contracting state-not merely to the competent authority of the state of residence. Reservations can be made according to Article 16(5) of the MLI, but only if the minimum standard is fulfilled in some of the ways provided for under this provision.

Article 17 of the MLI implements Article 9(2) of the OECD Model Tax Convention in the Covered Tax Agreement, which provides for an appropriate adjustment being made in transfer pricing cases and, if necessary, involvement of the competent authorities of the contracting states.

\subsubsection{Mandatory Binding Arbitration (Articles 18-26)}

The mutual agreement procedure provides a mechanism for resolving disputes in cases in which a taxpayer considers that the actions of one or both contracting states result in taxation that is not in accordance with the provisions of the treaty. Although this mechanism urges contracting states to resolve disputes, it does not require that they do so. In order to avoid unresolved disputes and to pressure the contracting states to come to a timely solution, provisions for mandatory binding arbitration can be implemented-meaning that under defined circumstances, the contracting states are obliged to submit unresolved mutual agreement disputes to an independent arbitration panel, the decision of which is binding.

Negotiation of the other parts of the MLI focused on implementing tax treaty changes developed through the BEPS Project, without changing the substance of the BEPS outputs and without creating new measures that were not developed during the BEPS Project. Work on mandatory binding arbitration, however, expressly included the development of the substantive content of mandatory binding arbitration provisions.

The provisions on mandatory binding arbitration have been included in Articles 18-26 of the MLI. As follows from Article 18, this part of the MLI is optional; thus it will apply only where both contracting states to a tax treaty have actively chosen to adopt it. At the time of signature, $25 \mathrm{ju}$ - risdictions had chosen to adopt the MLI arbitration provisions (OECD 2017e).

\subsection{The MLI Explanatory Statement}

In addition to the MLI itself, there is, as mentioned, the MLI Explanatory Statement-an 85-page document that provides comments to the Articles. According to the MLI Explanatory Statement, the text of the statement was prepared by the participants of the ad hoc Group and the SubGroup on Arbitration, in order to provide clarification of the approach taken in the MLI and to describe how each provision is intended to affect tax agreements covered by the MLI. It, therefore, reflects the agreed understanding of the negotiators with respect to the MLI (OECD 2016; see para. 11).

The MLI Explanatory Statement frequently refers to the previous OECD reports on BEPS and explains the purpose of the articles in general terms. Moreover, it deals with such technical aspects as how the articles of the MLI relate to provisions of existing tax treaties and to what extent and how a party to the MLI can make choices relating to the MLI. It provides little guidance for interpreting the provisions of the MLI.22 The development of the BEPS measures implemented by the MLI also included development of commentary, however, which is intended to be used in the interpretation of provisions implementing those measures. Consequently, the MLI Explanatory Statement states that it is intended to clarify the operation of the MLI to modify Covered Tax Agreements, but that it is not intended to address the interpretation of the underlying BEPS measures, except with respect to the mandatory binding arbitration provisions contained in Articles 18 through 26, which were developed simultaneously with the negotiation of the MLI (OECD 2016; see para. 12).

Furthermore, the MLI Explanatory Statement states that the provisions contained in Articles 3 through 17 should be interpreted in accordance with the ordinary principle of treaty interpretation - that a treaty shall be interpreted in good faith in accordance with the ordinary meaning to be given to the terms of the treaty in their context and in light of its object and purpose and that the object and purpose of the MLI is to implement the taxtreaty-related BEPS measures. Furthermore, it states that

22 See Bosman (2017), for a discussion on the interpretation of the MLI and, among other things, the general interpretation clause included in Art. 2(2) of the MLI, corresponding to the general interpretation clause in Art. 3(2) of the OECD Model Tax Convention. 
the commentary that was developed during the course of the BEPS Project and reflected in the Final BEPS Package has particular relevance in this regard, and whereas, in some cases, the provisions of the MLI differ in form from the model provisions produced through the BEPS Project, unless otherwise noted, these modifications are not intended to make substantive changes to those provisions.

The commentary that was developed during the course of the BEPS Project has been included in the most recent version of the OECD Model Tax Convention, which was published on December 18, 2017 (OECD 2017c). Insofar as the MLI will have implemented new provisions in an existing tax treaty, it will be relevant to look at the commentary for interpreting such provisions. The extent to which it is also relevant to look at the new commentary for interpreting unchanged provisions of existing treaties is a matter outside the scope of this publication.

Exceptionally, the MLI includes substantive provisions that had not been developed prior to the MLI (OECD 2016; see para. 66). ${ }^{23}$ Presumably, commentaries to those provisions have been or will be developed and, to the extent that the provisions will be reflected in future versions of the OECD Model Tax Convention, commentaries will likely also be included.

\section{Complexity and Uncertainty}

\subsection{Some Notes on Rule Complexity and Legal Uncertainty}

Up until now, taxation of international transactions has involved two "layers" of rules that need to be taken into account: domestic law and tax treaties. When the MLI enters into force, an additional layer is added. Except in simple tax matters, one has to read the existing tax treaty alongside the relevant parts of the commentary of the OECD Model Tax Convention plus the MLI (checking with the information provided by the Depositary to see whether the tax treaty in question is covered and which provisions apply between the treaty partners), together with the relevant parts of the MLI Explanatory Statement. The MLI is 48 pages long, and the MLI Explanatory Statement is 85 pages long, and, as pointed out by Baker (Baker 2017), not even its admirers would say that the MLI is the most transparent piece of drafting. Interpretation and application of tax treaties may become quite a challenge. Moreover, the

23 See Art. 5(4) of the MLI.
MLI contains anti-avoidance provisions, which, as is often the case with such provisions, contain vague wording and subjective elements that makes them less rules based and more discretionary in their application.

If the MLI fulfills its aim, on the other hand, it will reduce opportunities for certain forms of tax planning and could potentially streamline and update the tax treaty network. It is not the purpose of this publication, however, to determine whether the goals of the MLI are achieved to an extent that justifies its disadvantages. That would require research methods other than those used here. The purpose is merely to analyze the MLI in light of rule complexity and legal uncertainty.

Tax complexity and similar terms can mean many different things and may often, depending on how they are defined, include the way taxpayers perform necessary activities in completing their tax compliance tasks (Pedersen 2012). In Untangling the Income Tax, David Bradford (1986) distinguishes three types of tax complexity: compliance complexity, transactional complexity, and rule complexity. Compliance complexity refers to the problems faced by the taxpayer in tasks such as keeping records, choosing forms, and making necessary calculations; transactional complexity refers to the problems faced by taxpayers in organizing their affairs within the framework of the rules; and rule complexity refers to the problems of interpreting written and unwritten rules (Bradford 1986). The first two elements thus relate to the taxpayer's activities, whereas the last type of complexity relate to the rules themselves.

Although it seems reasonable to assume that an increase in rule complexity would result in an increase in the taxpayer's compliance burden and the administrative burden of the tax authority, studying the complexity of the rules is not sufficient to justify that conclusion. The costs of complexity cannot be measured by looking solely at the rules themselves (Pedersen 2012). For instance, digitalization, involving extensive reporting by employers and financial institutions that enables the production of preprinted tax returns, may improve taxpayers' performance and reduce compliance costs, in spite of increased rule complexity. In this article, which has a more limited scope, the focus is solely on rule complexity rather than compliance complexity or transactional complexity.

Uncertainty is sometimes seen as an element of tax complexity. In my view, however, there is reason to distinguish between complexity and uncertainty for the purpose of the following analysis.

A high level of rule complexity means that the rules are difficult to understand, perhaps because the relevant regulation is extensive and detailed or because it consists of many interrelated and interdependent parts that overlap 
or interact with each other. High rule complexity makes it very difficult to solve legal problems, and access to legal expertise in the relevant field of law may be an absolute requirement to solving legal issues within a reasonable time. A high level of rule complexity does not necessarily mean that the outcome is uncertain, however. Assuming that the relevant resources are available, it may be possible to reach a reasonably certain answer, in spite of rule complexity.

Legal uncertainty, on the other hand, means that it is not possible to make a reasonably certain prediction of how a public authority or court will decide in a legal matter, should the matter come to its attention..$^{24}$ Legal uncertainty may arise not only in situations in which the legislation is complex; ambiguous legislation or poor understanding of the legislation by public authorities and courts may also cause the uncertainty. And ambiguous legislation is often caused by the use of vague or subjective concepts in the legislation. Even though complexity and uncertainty are different concepts, there is likely a correlation between them, as complexity makes it more difficult for public authorities and the courts to achieve a good understanding of the legislation.

\subsection{The Impact of the MLI}

Before analyzing the consequences of the MLI for rule complexity and legal uncertainty, we need to estimate the actual impact of the MLI on the tax treaties of the world. The greater the impact, the greater is the consequences for rule complexity and legal uncertainty.

First, some jurisdictions may refrain from signing or ratifying the MLI, in which case their tax treaties will be unaffected by the MLI. This does not rule out the possibility that tax-treaty-related minimum standards agreed upon within the framework of the OECD BEPS Project are met or that other elements of the MLI are incorporated in tax treaties, but this will have to be done through bilateral negotiations. Second, parties to the MLI have the option of excluding some of their tax treaties from the scope of the MLI by refraining from listing them as Covered Tax Agreements. Third, as previously described, most of the provisions of the MLI do not reflect minimum standards. Where an MLI provision does not reflect a minimum stan-

24 This understanding of the concept of legal uncertainty excludes uncertainty regarding the future content of the legislation. (See, e.g., Hassett and Metcalf 1999, for a study on the impact of uncertain tax policy on investment.) dard, signatories have the option of making reservations against that provision, meaning that their tax treaties will be unaffected by that part of the MLI. Signatories can make reservations against each of the Articles $12-15$ on permanent establishments, for instance, so that the permanent establishment definition included in their tax treaties remains unchanged by the MLI. All these factors are important to consider when estimating the impact of the MLI.

If many jurisdictions were to make reservations against most or all provisions of the MLI that do not reflect minimum standards, the impact of those provisions on the tax treaties of the world would be greatly reduced. The collective impact of such reservations is larger than may be suggested by the proportion of jurisdictions making reservations. Where a jurisdiction has made a reservation against an article, that article will generally not apply to any of its Covered Tax Agreements. On the other hand, where a jurisdiction refrains from making a reservation against an article, that article does not become automatically applicable to all its tax treaties-but only to those covered by the MLI and in respect of which the other contracting state or jurisdiction has not made a reservation.

The impact of the MLI can be mathematically described as follows. The number of bilateral relations between jurisdictions that enter into tax treaties is $n(n-1) / 2$ or, written differently, $\left(n^{2}-n\right) / 2$, where $n$ stands for the number of jurisdictions that enter into tax treaties. ${ }^{25} \mathrm{In}$ practice, the number of existing tax treaties will be lower than the number of bilateral relations, as not all jurisdictions enter into tax treaties with each other. ${ }^{26}$ Similarly, the potential number of tax treaties between jurisdictions that are signatories to the MLI and has not made reservations against a specific article in its entirety is $\left(\mathrm{p}^{2}-\mathrm{p}\right) / 2$, where $p$ stands for the number of signatories that have not made reservations against that article in its entirety. The proportion of existing tax treaties affected by an MLI article in respect of which a reservation can be made is thus $\left(\mathrm{p}^{2}-\right.$ p)/( $\left.n^{2}-n\right)$. In practice, the share would be even lower, as some treaties of the parties to the MLI have not been listed

25 Each state can enter into a treaty with all other states, but not with itself. Consequently, the number of possible combinations of one state with another is $n$ times $n-1$. Two combinations, FranceGermany and Germany-France, for example, represent one bilateral relation, and the number of combinations is, therefore, divided by two.

26 Some jurisdictions may be parties to multilateral tax treaties such as the Nordic Tax Treaty, which contains rules that are bilateral in their nature and essentially function in the same way as would bilateral tax treaties between all the parties. 
as Covered Tax Agreements and are thus unaffected by the MLI.

It is not my intention to make an exact calculation of the proportion of tax treaties affected by an MLI article in respect of which a reservation can be made. The point is that if the proportion of jurisdictions that is party to the MLI and has not made a reservation in respect of a specific article in its entirety falls, then the proportion of the world's tax treaties modified by that article drops dramatically. If 100 jurisdictions entered into tax treaties with each other, for example, and 50 of them were parties to the MLI and had not made a reservation against an MLI article in its entirety, then the proportion of tax treaties that would be affected by that article would be less than $25 \%$ ([50 ${ }^{2}-$ $50] /\left[100^{2}-100\right] \approx 24.7 \%$ ). If 25 out of 100 were parties to the MLI and had not made a reservation against the article in question in its entirety, then only about $6 \%\left(\left[25^{2}-\right.\right.$ $25] /\left[100^{2}-100\right] \approx 6.1 \%$ ) of the tax treaties would be modified by that article. This correlation is illustrated in Figure 1.

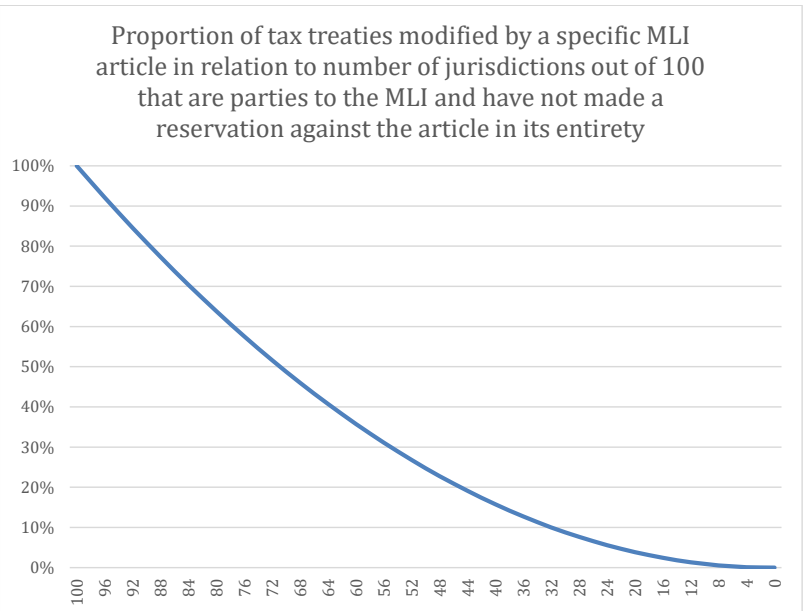

Figure 1: Impact of MLI articles that do not reflect minimum standards

Sweden is an example of a state that has made extensive reservations. It has reserved the right for the entirety of Articles 3-5 and 8-15 not to apply to its Covered Tax Agreements (OECD 2017a). Potentially, if many states choose to make reservations, the material impact of the MLI could become limited to a few core provisions that reflect minimum standards-mainly the introduction of a general tax treaty antiabuse provision in the form of a PPT clause.

As a test sample, to obtain an indication of the extent of the use of reservations, I have reviewed the positions (OECD 2017a) of the world's 20 largest economies
(World Bank 2017) in respect of the MLI and its articles on hybrid mismatches (Articles 3-5), the articles on treaty abuse that do not reflect a minimum standard (Articles 811), and the first three articles on the permanent establishment definition (Articles 12-14). ${ }^{27}$ If a majority of the states representing the world's largest economies were to make reservations against these articles such that they would not amend their existing tax treaties, that would indicate a substantially reduced effect of the MLI in regard to the provisions that do not reflect minimum standards. Where I refer to the MLI position of specific signatory states, the reference concerns the reservations expressed at the time of signature, either in the form of reservations that are subject to confirmation on deposit of the instruments of ratification or in the form of a provisional list of expected reservations. ${ }^{28}$

First, it can be noted that 3 of the 20 states-the United States, Brazil, and Saudi Arabia-have not signed the MLI (OECD 2017a). Unless they decide to join the signatories at a later time, their tax treaties will remain unaffected by the MLI. ${ }^{29}$

The other 17 major economies are listed in the lefthand column of Table 1 . If a state has reserved the right for the entirety of an article not to apply to any of its Covered Tax Agreements, this is indicated in the table by the letter R. Thus, the absence of the letter $\mathrm{R}$ indicates that the reservation concerns only a specific part of the article or specific Covered Tax Agreements or that no reservation has been made.

It follows from Table 1 that the 17 listed signatory states have made reservations against articles in their entirety in 78 cases out of 170 cases - a significant proportion (78/170 $46 \%)$. The reservations are not evenly distributed among the articles, however; the rate is lower in regard to some articles and well above $50 \%$ in others.

On the basis of these figures (which admittedly may not be representative of all signatories), it seems that the rate of reservations made against several articles may be around $50 \%$ of the signatories. The picture is confirmed in a recent study by Bosman (2017). Moreover, a number of jurisdictions are not parties to the MLI. Thus, in regard to several MLI articles, the proportion of jurisdictions that are parties to the MLI and have refrained from making a reser-

27 I have excluded Article 15 from the survey, as the inclusion of or reservation against that article, which contains a definition of "person $/ .$. / closely related to an enterprise", is a direct consequence of the choice in regard to the previous articles.

28 Cf. Section 2.6.

29 For a discussion on reasons for not signing, see Brauner (2018). 
Table 1: Reservations against articles in their entirety made by signatory states representing the world's 20 largest economies

\begin{tabular}{|c|c|c|c|c|c|c|c|c|c|c|}
\hline State/Article & 3 & 4 & 5 & 8 & $9^{30}$ & 10 & 11 & 12 & 13 & 14 \\
\hline China & $\mathrm{R}$ & - & - & - & - & $\mathrm{R}$ & - & $\mathrm{R}$ & $\mathrm{R}$ & $\mathrm{R}$ \\
\hline Japan & - & - & - & $\mathrm{R}$ & - & - & $\mathrm{R}$ & - & - & $\mathrm{R}$ \\
\hline Germany & $\mathrm{R}$ & $\mathrm{R}$ & - & - & - & - & $\mathrm{R}$ & $\mathrm{R}$ & - & $\mathrm{R}$ \\
\hline United Kingdom & - & - & - & $\mathrm{R}$ & $\mathrm{R}$ & $\mathrm{R}$ & - & $\mathrm{R}$ & - & $\mathrm{R}$ \\
\hline France & $\mathrm{R}$ & $\mathrm{R}$ & $\mathrm{R}$ & - & - & $\mathrm{R}$ & $\mathrm{R}$ & - & - & - \\
\hline India & $\mathrm{R}$ & - & $\mathrm{R}$ & - & - & - & - & - & - & - \\
\hline Italy & $\mathrm{R}$ & $\mathrm{R}$ & -31 & $\mathrm{R}$ & - & $\mathrm{R}$ & $\mathrm{R}$ & $\mathrm{R}$ & - & $\mathrm{R}$ \\
\hline Canada & $\mathrm{R}$ & $\mathrm{R}$ & $\mathrm{R}$ & $\mathrm{R}$ & $\mathrm{R}$ & $\mathrm{R}$ & $\mathrm{R}$ & $\mathrm{R}$ & $\mathrm{R}$ & $\mathrm{R}$ \\
\hline South Korea & $\mathrm{R}$ & $\mathrm{R}$ & $\mathrm{R}$ & $\mathrm{R}$ & $\mathrm{R}$ & $\mathrm{R}$ & $\mathrm{R}$ & $\mathrm{R}$ & $\mathrm{R}$ & $\mathrm{R}$ \\
\hline Russia & - & - & $\mathrm{R}$ & - & - & - & - & - & - & - \\
\hline Spain & - & $\mathrm{R}$ & - & - & - & - & $\mathrm{R}$ & - & - & $\mathrm{R}$ \\
\hline Australia & - & - & - & - & - & $\mathrm{R}$ & - & $\mathrm{R}$ & - & - \\
\hline Mexico & - & - & - & - & - & - & - & - & - & $\mathrm{R}$ \\
\hline Indonesia & $\mathrm{R}$ & - & $\mathrm{R}$ & - & - & $\mathrm{R}$ & - & - & - & - \\
\hline Turkey & - & $\mathrm{R}$ & $\mathrm{R}$ & $\mathrm{R}$ & - & $\mathrm{R}$ & $\mathrm{R}$ & - & - & $\mathrm{R}$ \\
\hline Netherlands & - & - & - & - & - & - & $\mathrm{R}$ & - & - & - \\
\hline Switzerland & $\mathrm{R}$ & $\mathrm{R}$ & - & $\mathrm{R}$ & $\mathrm{R}$ & $\mathrm{R}$ & $\mathrm{R}$ & $\mathrm{R}$ & $\mathrm{R}$ & $\mathrm{R}$ \\
\hline $\begin{array}{l}\text { Number of reserva- } \\
\text { tions }\end{array}$ & 9 & 8 & 7 & 7 & 4 & 10 & 10 & 8 & 4 & 11 \\
\hline
\end{tabular}

vation may fall well below 50\%. In addition, a tax treaty between two parties to the MLI may be unaffected by the MLI because one or both parties has refrained from listing it as a Covered Tax Agreement, further reducing the proportion of tax treaties affected. Consequently, several MLI articles will modify only a small percentage of the existing tax treaties. ${ }^{32}$

Although the reason many states seem to have made reservations would be an interesting issue to study, it is outside the scope of this article. Protecting business is presumably a key reason. The complexity of the instrument, the time constraints, and the difficulties in determining the effect of the MLI on the overall balance of individual treaties may also have played a role in this regard (Schwarz 2017a). In retrospect, one wonders whether it would have been wiser to have a multilateral agreement solely on treaty abuse, which adopts only the PPT, perhaps

30 With regard to Art. 9, a reservation against Art. 9(1) without opting in to Art. 9(4) has been deemed a reservation against the article in its entirety, as it would mean that the article is not given any effect.

31 Italy has not chosen to apply any of the options under Art. 5 but accepts that the other contracting state changes its method for elimination of double taxation and, therefore, does not make a reservation. 32 In contrast, Brauner (2018) argues that "the MLI should not be dismissed as a mechanism forcing parties to gravitate toward the lowest common denominator." conditional on minimum standards of dispute resolution, and a stand-alone multilateral agreement on arbitration (Schwarz 2017b). This would have been much less complex and would not have risked resulting in fragmentation of the design of tax treaties.

As described, the reservations and notifications are subject at this stage to confirmation or merely provisional and may thus be amended before the MLI enters into force. It is unlikely, however, that the MLI positions would be amended to the extent that this would change the overall picture.

\subsection{Rule Complexity and Legal Uncertainty Caused by the Multilateral Instrument}

\subsubsection{Rule Complexity}

As mentioned, rule complexity can follow from extensive and detailed regulations or regulations that consist of many interrelated and interdependent parts that overlap or interact with each other. The MLI is undoubtedly extensive, detailed, and technical in nature. Furthermore, the complexity of the way it interacts with existing treaties is underlined by the fact that an 85-page Explanatory Statement is required to provide clarification of the approach taken in the MLI and of the operation of the MLI to mod- 
ify existing tax treaties. Some rules provided in the MLI are particularly complicated, including the so-called simplified limitation on benefits provision in Article 8, which stretches over four pages. And the complexity of the MLI is also enhanced by the fact that it is a flexible instrument that allows for an almost infinite number of combinations of reservations and options. Insofar as parties to the MLI will use such reservations and options, their implementation of the MLI will rarely be identical. Reading and understanding the MLI is no easy task, even for a lawyer working full time with international tax matters. For the layperson, the MLI may be perceived as impenetrable.

There are also some factors that may reduce the complexity, however, or at least facilitate application of the MLI in practice. For instance, the system of notifications of Covered Tax Agreements, reservations, and options and of provisions in existing tax treaties that are modified by the MLI eliminates many difficulties concerning the interaction between the MLI and existing tax treaties. Moreover, the fact that such notifications are easily accessible via the OECD website can probably reduce compliance costs significantly. The preparation of consolidated tax treaty texts that present the treaty texts as modified by the MLI or other forms of guidance about the modifications can also contribute in this direction.

A multilateral approach to updating tax treaties could potentially result in the streamlining of tax treaties, reducing complexity in the rules governing taxation of international transactions and investment. As long as the instrument remains flexible and states use that flexibility, streamlining will be limited, however. It is even possible that the MLI will lead to increased fragmentation and undermine the considerable uniformity in the design of tax treaties achieved over the past few decades through the OECD Model Tax Convention.

As demonstrated here, several MLI articles may modify only a small percentage of existing tax treaties. If so, the fragmentation and the increase in rule complexity that could have been potentially caused by the MLI will be substantially reduced. The material impact of the MLI will be essentially limited to the articles that represent minimum standards and, in particular, the introduction of the PPT provision.

\subsubsection{Legal Uncertainty}

As mentioned, the MLI leads to an increase in rule complexity, but there are some factors that limit that increase. For instance, as shown here, several MLI articles that the signatories can make reservations against may in practice amend only a small percentage of the existing tax treaties. Other MLI articles reflect minimum standards, however, and will, therefore, have a much stronger impact. Article 6, which reflects a minimum standard, modifies the preamble text of existing tax treaties to clarify that the purpose of the tax treaties is to eliminate double taxation without creating opportunities for non-taxation or reduced taxation through tax evasion or avoidance. This revised preamble could possibly have some significance for the interpretation of tax treaties, but it is difficult to say to what extent. Even in the absence of this kind of preamble text, tax treaties may have been interpreted as having goals other than the elimination of double taxation.

The most significant change is probably the introduction of a PPT provision, which is a novelty in the tax treaty context. Although the minimum standard could, in theory, be met without a PPT provision, to date, all signatories have chosen to implement the minimum standard with the PPT. The PPT provision introduces a subjective element in tax treaties that did not previously exist. It can be argued that one of the strengths of tax treaties was their reliance on objective criteria, creating some degree of certainty in a highly complex and uncertain international tax environment, involving the different and generally uncoordinated tax legislations, tax administrations, and courts of at least two jurisdictions.

It is considered a fundamental element of a democratic society that rules imposing rights and obligations on individuals are clear and precise, so that the individuals may know their rights and obligations without ambiguity and be able to take the appropriate steps. ${ }^{33}$ This presupposes that such rights and obligations follow from the law rather than the exercise of discretion and that the law is accessible and, so far as possible, intelligible, clear, and predictable (Bingham 2010). Legal certainty may be valuable not only because it embodies and encourages a just society but also because it contributes to economic growth by reducing risk that would otherwise discourage investment. Empirical evidence is limited, but what little there is suggests that tax uncertainty is a key factor for enterprises' investment decisions (Devereux 2016 and IMF-OECD 2017). Although this research has focused on uncertainty with regard to future tax legislation (e.g., due to shifting tax policy) rather than legal uncertainty (the difficulty in predicting how public authorities and courts will decide in specific legal matters), it is consistent with the general percep-

33 Cf. Case 169/80 Administration des douanes v Société anonyme Gondrand Frères and Société anonyme Garancini [1981], ECR 1931, p. 17. 
tion that uncertainty (be it in regard to future legislation or to the meaning of current legislation) is negative for investment.

The various objectives of a good tax structure are not necessarily in agreement, and where they conflict, tradeoffs between them are required. An equitable distribution of the tax burden, for example, may require administrative complexity (Musgrave and Musgrave 1989). Similarly, the goal of preventing extensive tax planning may be contrary to the objective of making the legislation clear and precise in the interest of legal certainty. Moreover, the correlation between uncertainty and vague and ambiguous rules is not always straightforward. If the existence of a PPT provision was to deter taxpayers from engaging in aggressive tax planning (whatever that is), it could lead to a reduction of uncertainty (Blouin et al. 2012). It would not necessarily reduce legal uncertainty per se, but it could reduce the number of instances in which taxpayers are faced with that legal uncertainty. Thus, some degree of vagueness may be justified. The question is whether the inclusion of the PPT rule in tax treaties constitutes a successful trade-off.

Taxpayers choosing among various courses of action are not generally obliged to choose the option that results in the highest tax liability. To take a simple example, assume that a shareholder is about to vote for a dividend to be paid but learns that bilateral tax treaty negotiations for a lower withholding tax limitation on dividends are being undertaken. The taxpayer, therefore, makes an agreement with the other taxpayers to delay the decision to distribute dividends until the following year in order to benefit from the lower limit on the withholding tax. Probably, most (if not all) people would regard this as an acceptable form of tax planning, and few would claim that General Anti-Avoidance Rules (GAARs) such as the PPT rule would apply. Yet, obtaining the benefit (a lower withholding tax rate) was the principal purposes of the arrangement (the agreement with the other shareholders), which means that the treaty benefits shall not be granted unless it can be established that granting the benefit would be in accordance with the object and purpose of the relevant provision of the treaty. In my view, it would be in accordance with the object and purpose of the relevant provision to grant the treaty benefit. The PPT rule is so vague, however, that its scope will be largely up to the official or judge applying it, so it cannot be ruled out that someone else would take a different view. As mentioned, if relevant resources such as legal expertise are available, it may be possible to reach a reasonably certain answer in spite of rule complexity. Where, on the other hand, the content of the rules is uncertain, it may be impossible to make a reasonably certain prediction of how a public authority or court would decide in a legal matter, regardless of the costs spent on legal expertise.

There is a significant risk that the PPT rule, at least in some jurisdictions, will be applied to situations that most taxpayers consider to be uncontroversial and acceptable tax planning. Assume, for instance, that a company group sets up a holding company to coordinate investments into other jurisdictions. Establishing the holding company as such may have purposes other than achieving a tax benefit, but the choice of jurisdiction for the holding company may be strongly influenced by tax reasons. Would this mean that the tax authority can invoke the PPT provision in order to refuse the granting of treaty benefits to the holding company? Different views may be taken, either as a result of different interpretations of the PPT provision or because the evidence of the case is weighed differently.

To some extent, improvements of the mutual agreement procedure implemented through the MLI or otherwise, including binding mandatory arbitration, can counteract legal uncertainty. In practice, however, such measures can be applied to relatively few cases. Moreover, such measures generally come into play after an investment or transaction has been made and may, therefore, be ineffective in reducing uncertainty that could discourage investment.

If there were consensus on the meaning of aggressive tax planning and if the PPT rule would have been formulated in such a way as to capture only such forms of tax planning, then the legal uncertainty would clearly have been justified. As the scope of the PPT rule may depend largely on the subjective view of the person applying it, however, taxpayers will frequently be unable to determine beforehand whether it will apply or not, and the negative effects of legal uncertainty caused by the PPT rule may be greater than its merits. It remains to be seen whether the PPT provision proves to be entirely vague and uncertain and undermines the reliance that taxpayers could place on tax treaties (Baker 2017).

One question is whether there is anything that can be done to reduce the negative effects. One way of mitigating the legal uncertainty caused by the PPT is to provide clear guidance on the scope of the PPT provision in the upcoming versions of the commentary to the OECD Model Tax Convention. In line with the general object and purpose of the MLI of counteracting BEPS, the guidance could emphasize that the PPT rule is applicable to treaty abuse that would result in BEPS but not to any kind of tax planning. Yet it is difficult to define what is meant by BEPS, and it is inherently difficult to provide clear guidance on rules that are as vague as the PPT rule. The commentary could detail a number of examples of situations to which the PPT 
rule would typically apply and, just as important, examples of situations to which it would typically not apply. Some helpful examples are provided in the Final Report on Action 6 (OECD 2015b), which have essentially found their way into the commentaries of the 2017 OECD Model Tax Convention, and a few examples have been added, but further examples would be welcome. To include clear guidance in the commentaries, however, requires that there be a certain degree of consensus as to the scope of the PPT rule. It is doubtful if any such consensus exists.

\section{Conclusions}

The MLI is extensive, detailed, and technical in nature. It also interacts with existing tax treaties in an intricate way, as underlined by the fact that an 85-page Explanatory Statement is required to provide clarification of the approach taken in the MLI and of the operation of the MLI to modify existing tax treaties. Some MLI provisions are remarkably complicated, such as the so-called simplified limitation on benefits provision in Article 8, which stretches over four pages. The complexity of the MLI follows partly from the fact that it is a flexible instrument that allows for an almost infinite number of combinations of reservations and options.

Moreover, the MLI introduces a subjective element in tax treaties that did not previously exist (other than as a guiding principle in the commentary to the OECD Model Tax Convention). In particular, the MLI introduces an antiabuse provision in the form of the so-called PPT provision. The provision, which is included in Article 7 of the MLI and since the 2017 update in Article 29(9) of the OECD Model Tax Convention, provides that treaty benefits shall be denied if it is

reasonable to conclude, having regard to all relevant facts and circumstances, that obtaining that benefit was one of the principal purposes of any arrangement or transaction that resulted directly or indirectly in that benefit, unless it is established that granting that benefit in these circumstances would be in accordance with the object and purpose of the relevant provisions of the Covered Tax Agreement.

The subjective nature of this provision makes it difficult to make a reasonably certain prediction on whether treaty benefits will be denied in a given situation. In other words, it may give rise to legal uncertainty.

To obtain a clearer picture of whether the MLI will in fact lead to an increase in rule complexity and legal uncertainty, one must first estimate the impact of the MLI on existing tax treaties. Parties to the MLI can make reservations against provisions of the MLI that do not reflect minimum standards. Where a jurisdiction has made a reservation against an article, that article will generally not apply to any of its Covered Tax Agreements. Parties to the MLI may also exclude some of their tax treaties from the scope of the MLI. Moreover, some states have not signed the MLI, which of course means that their tax treaties will remain unaffected by it. In this paper, I have shown that several MLI provisions may, as a consequence, affect only a small proportion of the world's tax treaties. As a result, the material impact of the MLI could become limited to a few core provisions that reflect minimum standards. The most significant impact of the MLI will probably be the introduction of the PPT provision in tax treaties. Although, in theory, the minimum standard could be met without a PPT provision, all signatories to date have chosen to implement the minimum standard with the PPT.

Consequently, the increase in rule complexity may not be as significant as indicated by looking solely at the MLI. As mentioned, however, the PPT provision introduces into tax treaties a subjective element that did not previously exist. It can be argued that one of the strengths of tax treaties was their reliance on objective criteria and their ability to create some degree of certainty in a complex and uncertain international tax environment and that this feature of tax treaties will be lost to some extent through the introduction of the PPT rule.

\section{References}

Baker, Philip. 2017. "The Multilateral Convention to Implement Tax Treaty Related Measures to Prevent Base Erosion and Profit Shifting” British Tax Review (3): 281-4.

Bingham, Tom. 2010. The Rule of Law. London: Penguin Books.

Blouin, Jennifer L., Devereux, Michael, and Shackelford, Douglas A. 2012. "Investment, Tax Uncertainty, and Aggressive Tax Avoidance", mimeo.

Bosman, Alexander. 2017. "General Aspects of the Multilateral Instrument" Intertax 45 (10): 642-59.

Bradford, David F. 1986. Untangling the Income Tax. Cambridge, Massachusetts: Harvard University Press.

Brauner, Yariv. 2018. "McBEPS: The MLI - The First Multilateral Tax Treaty that Has Never Been" Intertax 46 (1): 6-17.

Chand, Vikram. 2018. "The Principal Purpose test in the Multilateral Convention: An in-depth Analysis" Intertax 46 (1): 18-44.

Devereux, Michael. 2016. "Measuring corporation tax uncertainty across countries: Evidence from a cross-country survey”. Oxford University Centre for Business Taxation.

Engsbråten, Alf. 2017. "Hur kommer Sveriges undertecknande av det multilaterala instrumentet att påverka svenska skatteavtal?" Svensk Skattetidning (6-7): 397-412. 
Hasset, Kevin A., and Gilbert E. Metcalf. 1999. “Investment with Uncertain Tax Policy: Does Random Tax Policy Discourage Investment?" The Economic Journal 109 (457): 372-93.

IMF (International Monetary Fund) and OECD (Organisation for Economic Co-operation and Development). 2017. IMF/OECD Report for the G20 Finance Ministers.

Kofler, Georg. 2016. "Some Reflections on the 'Saving Clause”'. Intertax 44 (8/9): 574-89.

Mosquera Valderrama, Irma. 2015. "Legitimacy and the Making of International Tax Law: The Challenges of Multilateralism." World Tax Journal 7 (3): 343-82.

Musgrave, Peggy, and Musgrave, Richard. 1989. Public Finance in Theory and Practice. 5th ed. Singapore: McGraw Hill Book Company.

OECD (Organisation for Economic Co-operation and Development). 2013. "Action Plan on Base Erosion and Profit Shifting". Paris: OECD Publishing.

OECD (Organisation for Economic Co-operation and Development). 2014. "Developing a Multilateral Instrument to Modify Bilateral Tax Treaties". Paris: OECD Publishing.

OECD (Organisation for Economic Co-operation and Development). 2015a. "Developing a Multilateral Instrument to Modify Bilateral Tax Treaties, Action 15 - 2015 Final Report”. Paris: OECD Publishing.

OECD (Organisation for Economic Co-operation and Development). 2015b. "Preventing the Granting of Treaty Benefits in Inappropriate Circumstances, Action 6 - 2015 Final Report”. Paris: OECD Publishing.

OECD (Organisation for Economic Co-operation and Development). 2016. "Explanatory Statement to the Multilateral Convention to Implement Tax Treaty Related Measures to Prevent Base Erosion and Profit Shifting". Paris: OECD Publishing.

OECD (Organisation for Economic Co-operation and Development). 2017a. Signatories and Parties to the Multilateral Convention to Implement Tax Treaty Related Measures to Prevent Base Erosion and Profits Shifting. Status as of 20 December 2017. http://www.oecd.org/tax/treaties/beps-mli-signatories-and-par ties.pdf, accessed 22 January 2018.
OECD (Organisation for Economic Co-operation and Development). 2017b. Toolkit for Application of the Multilateral Instrument for BEPS Tax Treaty Related Measures, Legal Note on the Functioning of the MLI under Public International Law. http://www.oecd.org/tax/treaties/application-toolkit-multilater al-instrument-for-beps-tax-treaty-measures.htm, accessed 29 September 2017.

OECD (Organisation for Economic Co-operation and Development). 2017c. "Model Tax Convention on Income and on Capital: Condensed Version 2017". Paris: OECD Publishing.

OECD (Organisation for Economic Co-operation and Development). 2017d. Frequently Asked Questions on the Multilateral Instrument (MLI). https://www.oecd.org/tax/treaties/MLI-frequently-askedquestions.pdf, accessed 29 September 2017.

OECD (Organisation for Economic Co-operation and Development). 2017e. Ground-breaking multilateral BEPS convention signed at OECD will close loopholes in thousands of tax treaties worldwide. http://www.oecd.org/tax/ground-breaking-multilateral-beps-con vention-will-close-tax-treaty-loopholes.htm, accessed on 29 September 2017.

Pedersen, Frank H. 2012. "Advancing the Study of Tax Complexity with the Usability Model" Houston Business and Tax Law Journal XII (2): 282-361.

Schwarz, Jonathan. 2017a. Multilateral Negotiation of Bilateral Treaties. Kluwer International Tax Blog. http://kluwertaxblog.com /2017/02/21/multilateral-negotiation-of-bilateral-treaties/, accessed 28 September 2017.

Schwarz, Jonathan. 2017b. The BEPS MLI - Artificial Intelligence Needed. Kluwer International Tax Blog. http://kluwertaxblog.com /2017/06/22/beps-mli-artificial-intelligence-needed/, accessed 28 September 2017

World Bank. 2017. World Development Indicators database. http://databank.worldbank.org/data/download/GDP.pdf, accessed 29 September 2017. 